\title{
STRATEGI ADAPTASI PKL KOTA SEMARANG: KAJIAN TENTANG TINDAKAN SOSIAL
}

\author{
Agus Maladi Irianto \\ Fakultas Ilmu Budaya, Universitas Diponegoro, Semarang, Indonesia
}

Permalink/DOI: http://dx.doi.org/10.15294/komunitas.v6i1.2938

\begin{tabular}{l} 
Article History \\
\hline Received : Desember 2013 \\
Accepted : Januari 2014 \\
Published : Maret 2014
\end{tabular}

\section{Keywords}

street vendor; social action; informal sector; social network; adaptation strategy

\begin{abstract}
Abstrak
Tulisan berikut merupakan penelitian kualitatif mengenai strategi adaptasi pedagang kaki lima (PKL) dalam menandai tindakan sosial manusia yang menandai dinamika kegiatan ekonomi di perkotaan (khususnya di Kota Semarang). Tujuan yang ingin dicapai dari kajian ini adalah tersajikannya lukisan mendalam mengenai pola-pola usaha di sektor informal, serta penciptaan jaringan sosial di antara keluarga PKL dalam rangka mengisi lapangan pekerjaan di perkotaan. Sejumlah tindakan sosial manusia, khususnya yang dilakukan para PKL dalam penelitian ini, menyiratkan tentang tindakan sosial manusia yang kemudian mengkonstruksi konsep jaringan sosial dan strategi adaptasi PKL Kota Semarang.
\end{abstract}

\section{ADAPTATION STRATEGIES OF STREET VENDOR IN SEMARANG: A STUDY OF SOCIAL ACTION}

\begin{abstract}
The following article is a qualitative research about the adaptation strategy of street vendors in marking the human's social action that marks the dynamic of economic activities in urban areas (especially in Semarang). The objectives of this study are presenting in-depth portrait of the business patterns in the informal sector, and the creation of social networks among street vendors' families in order to fill the job fields in urban area. Several human's social actions, especially conducting by the street vendors in this research, imply about human social action which then construct the concept of social networking and adaptation strategies of the street vendors in Semarang city.
\end{abstract}

(C) 2014 Universitas Negeri Semarang

$\triangle$ Corresponding author :

ISSN 2086-5465

Address: J1.Prof. H. Soedarto, S.H., Tembalang, Semarang

E-mail: agusmaladi@undip.ac.id 


\section{PENDAHULUAN}

Kemiskinan di perkotaan - terutama yang terjadi di Indonesia - pada dasarnya bermula dari terjadinya kemiskinan di pedesaan. Menurut sejumlah ahli, masalah tenaga kerja dan urbanisasi menciptakan kemiskinan di perkotaan berkaitan erat dengan munculnya kemiskinan di pedesaan. Kemiskinan di pedesaan dibuktikan dengan menurunnya jumlah penduduk yang tetap bekerja sebagai petani dan buruh tani (bandingkan pada Boiroh, 1973, Breman, 1980, dan Sayogo, 2002).

Kondisi tersebut mengakibatkan arus urbanisasi tidak bisa dihindari. Dengan tidak ada lagi lahan pekerjaan di desa membuat kota diisi orang-orang desa dengan kultur agraris. Para petani melakukan urbanisasi ke kota dan memilih pekerjaan baru di perkotaan pada dasarnya telah terjadi penyesuaian struktural. Dalam kasus migrasi petani Jawa misalnya, pengalihan dari pertanian telah membuat pendapatan dan curahan tenaga petani meningkat. Padahal, latar belakang orang-orang desa yang berkultur agraris itu akan berbenturan dengan gaya kehidupan industri di perkotaan. Hal itu, tentu bertolak dari kenyataan bahwa tidak semua penduduk kota terlibat atau memperoleh pekerjaan dari pabrik, atau perusahaan, atau kantor pemerintah, yang lazim disebut sektor formal. Justru tidak sedikit di antara penduduk kota yang tertampung di sektor bukan formal, atau lazim disebut sektor informal. Jika bertolak dari pendapat tersebut, lalu apa yang menentukan perbedaan antara sektor formal dengan sektor informal?

Breman (1980: 1-35) berpendapat sektor formal digunakan dalam pengertian pekerja bergaji, seperti pekerjaan dalam industri dan kantor pemerintah. Hal itu meliputi: (a) sejumlah pekerjaan yang saling berhubungan dan merupakan bagian dari struktur pekerjaan yang terjalin secara terorganisasi; (b) pekerjaan yang secara resmi terdaftar statistik perekonomian; dan (c) syarat-syarat bekerja dilindungi oleh hukum. Sedangkan perekonomian yang tidak memenuhi kriteria tersebut, dimasukkan dalam istilah sektor informal (suatu istilah yang mencakup pengertian berbagai kegiatan yang dalam istilah umum disebut sebagai "usaha sendiri"). Sektor informal biasanya sulit dicacah dan sering terlupakan dalam sensus resmi. Sektor informal seringkali didefinisikan sebagai usaha-usahan tingkah rendahan yang hanya membutuhkan sedikit modal dan digambarkan ketidakmenentuan pekerjaan dan pendapatan (bandingkan pada Sanchez (1981, 144-158). Sektor informal juga dianggap sebagai sistem ekonomi yang mempunyai peran sebagai katup pengaman ekonomi nasional belum diimbangi dengan proteksi atau perlindungan dari pemerintah (Rini, 2012). Jenis pekerjaan yang termasuk dalam sektor informal antara lain adalah, pedagang kaki lima, penjual koran, penyemir sepatu, penjaga kios, pengemis, pelacur, dan yang lain.

Di antara sejumlah jenis pekerjaan yang dilakukan dalam sektor informal tersebut, ternyata jenis pedagang kaki lima (PKL) oleh sejumlah ahli ilmu sosial merupakan salah satu pekerjaan yang penting dan nyata di sejumlah negara berkembang dan mampu memecahkan tingkat kemiskinan di perkotaan (bandingkan pada Bromley, 1978 dan Sanchez, dkk. 1981).

Berdasarkan sejumlah gambaran tersebut, maka dalam penelitian ini akan mencoba mengkaji topik keberadaan PKL. Topik ini dipilih dengan dua pertimbangan sebagai berikut: Pertama, keberadaan PKL sangat menandai dinamika dan mobilitas di perkotaan (Afrika, Asia, Timur Tengah, dan Amerika Latin). Bahkan, Kedua, keberadaan PKL merupakan salah satu di antara sejumlah usaha di sektor informal yang kehadirannya menjadi "jawaban terakhir" proses pertumbuhan kesempatan kerja yang lambat dalam sektor industri dan kemiskinan di lingkungan perkotaan.

Sejumlah pendapat mengungkapkan, di satu sisi PKL merupakan salah satu usaha di sektor informal yang mampu mengatasi kemiskinan perkotaan - karena ia yang padat karya (membutuhkan modal yang tidak terlalu besar), mandiri, bersifat kewiraswastaan, dan tak terlalu banyak menggantungkan pada uluran tangan pemerintah (bandingkan pada Broomley, 1978). Akan tetapi, 
di sisi lain, PKL merupakan pekerjaan yang rawan terhadap sejumlah resiko, ketidakmenentuan usaha, keamanan (diperas petugas keamanan dan preman), bertentangan dengan penataan kota (dikejar-kejar petugas pemerintah karena menciptakan kesemrawutan lingkungan), maupun munculnya persaingan tidak sehat (bandingkan pada McGee, 1973).

Dari sinilah muncul pertanyaan penelitian: Mengapa para PKL tetap bertahan mengembangkan usahanya, padahal pekerjaan tersebut sangat rawan terhadap sejumlah resiko, baik menyangkut kenyamanan, keamanan, dan persaingan yang tidak sehat?

Untuk menjawab pertanyaan tersebut, maka dirumuskan dalam sejumlah hipotesis. Hipotesis berikut sebagai jawaban sementara yang tujuannnya tidak untuk diuji, tetapi sebagai pemandu penelitian lapangan.

Pertama, PKL merupakan usaha yang tidak permanen dan menguntungkan secara ekonomi. Jika pedagang kaki lima merupakan usaha yang tidak permanen, maka sewaktu-waktu pekerjaan itu jika tidak menguntungkan secara ekonomis akan mudah ditinggalkan atau berganti usaha lain. Akan tetapi, jika pekerjaan itu menguntungkan secara ekonomis, maka sejumlah resiko akan dihadapi demi mengembangkan usaha tersebut. Jika sejumlah resiko akan dihadapi demi mengembangkan usaha tersebut, maka dibutuhkan sejumlah strategi bagi para pedagang kaki lima dalam mengatasi resiko tersebut (bandingkan pada Broomley, 1978, Lukman, 1995, Munir, 1993, dan Saleh, 1995)

Kedua, menekuni usaha sebagai PKL tidak membutuhkan pendidikan yang terlalu tinggi. Jika latar belakang pendidikan tidak menjadi persyaratan utama, maka sebenarnya pekerjaan sebagai pedagang kaki lima bisa dilakukan oleh siapa saja. Jika pekerjaan sebagai PKL bisa dilakukan oleh siapa saja, maka para urbanis dari desa yang berlatar belakang petani pun bisa menekuni usaha pedagang kaki lima. Jika urbanis dari desa yang berlatar belakang petani pun bisa menekuni usaha PKL, maka kemam- puan untuk menjalankan usaha - yang berbeda dengan sektor agraris - harus dilakukan melalui pemagangan. Jika kemampuan menjalankan usaha sebagai PKL harus dilakukan dengan pemagangan, maka diperlukan adanya seseorang penampung yang bisa dijadikan sarana belajar bagi calon PKL. Jika calon PKL membutuhkan seseorang penampung yang dapat dijadikan sarana belajar mereka, maka keluarga terdekatlah yang bisanya menerima kehadiran mereka (bandingkan pada Ali, 1989, Bairoh, 1973, Breman, 1980, dan Latief, 1977).

Ketiga, berusaha sebagai pedagang kaki lima biasanya tidak membutuhkan modal yang terlalu besar. Jika mengembangkan usaha PKL tidak membutuhkan modal besar, maka dengan kemampuan modal keuangan sendiri atau bantuan keluarga dapat mendorong seseorang menjadi PKL . Jika seseorang membuka usaha sebagai PKL hanya dengan modal sendiri, maka keberadaan pedagang kaki lima sebenarnya keberadaan pedagang kaki lima bisa disikapi sebagai jenis usaha yang mandiri. Jika seseorang membuka usaha sebagai PKL dengan modal bantuan keluarga, maka resiko kerugian serta pengembangan usaha akan ditanggung bersama anggota keluarga tersebut. Jika resiko kerugian serta pengembangan usaha akan ditanggung bersama anggota keluarga, maka masing-masing anggota keluarga yang menekuni pekerjaan PKL akan berusaha mengembangkan strategi bersama (bandingkan pada Ernawati, 1995, Jamuin, 2000, dan Suharyanti.dkk, 1995).

Sedangkan menyangkut tujuan penelitian ini, pada dasarnya akan mengkaji secara kualitatif mengenai strategi bertahan PKL dalam menandai dinamika kegiatan ekonomi di perkotaan. Tujuan yang ingin dicapai dari kajian ini adalah tersajikannya lukisan mendalam mengenai pola-pola usaha di sektor informal, serta penciptaan jaringan sosial di antara keluarga pedagang dalam rangka mengisi lapangan pekerjaan di perkotaan.

\section{METODE PENELITIAN}

Penelitian yang dilakukan pada tahun 
2010 ini bertolak dari data sekunder dan data primer. Data sekunder berupa sejumlah referensi secara tertulis tentang keberadaan PKL, terutama di perkotaan. Data primer berupa data tentang perekonomian keluarga PKL dan pola-pola adaptasi yang dikembangkan keluarga tersebut dalam menghadapi lingkungan dan sumber daya yang ada, dan data historis kehidupan keluarga PKL, serta kondisi rumah tangga mereka dalam mengembangkan usahanya. Data-data tersebut dikaji dari penelitian lapangan yang dilakukan di lokasi Kota Semarang, khususnya di seputuar Jalan Brotojoyo, Kokrosono, dan Poncowolo Semarang Barat.

Sedangkan subjek kajian sekaligus menjadi informan penelitian ini, adalah keluarga pedagang kaki lima membuka usaha di lokasi penelitian tersebut dengan kriteria sebagai berikut: (1) berlatar belakang keluarga petani, (2) meninggalkan pekerjaannya sebagai petani mengalihkan pekerjaannya ke sektor informal, dan (3) menekuni pekerjaan yang sama dengan anggota keluarga yang lain sebagai PKL.

Menyangkut teknik pengumpulan data, pada penelitian ini dilakukan dengan dua cara, yakni: (1) dengan membaca sumber-sumber kepustakaan atau penggunaan bahan-bahan tertulis yang dipandang relevan dengan masalah penelitian; dan (2) dengan melakukan penelitian lapangan (field work). Penggunaan bahan-bahan tertulis ditujukan untuk menunjang data lapangan. Di samping itu, bahan-bahan tertulis juga membantu peneliti mendapatkan teori-teori dan konsep-konsep yang telah dikemukakan oleh para ahli terdahulu. Dari bahan tertulis akan diperoleh orientasi yang lebih luas mengenai topik yang sedang dikaji, menghindarkan dari duplikasi penelitian, serta dapat mengungkapkan pikiran secara sistematis dan kritis. Dalam kaitannya dengan topik penelitian ini, maka bahan tertulis yang peneliti kumpulkan berupa tulisan-tulisan yang dimuat di media massa, laporan-laporan penelitian, jurnaljurnal, dan buku-buku yang berkaitan dengan masalah kemiskinan perkotaan, sektor informal dan PKL.
Sedangkan pengumpulan data yang dilakukan melalui penelitian lapangan dapat dilakukan dalam dua tahapan utama, antara lain: Pertama, tahap orientasi dan eksplorasi yang bersifat menyeluruh, atau menurut istilah Spradley (1980: 73-80), disebut sebagai grand tour observation. Pada tahap ini peneliti melakukan wawancara, dialog, atau diskusi-diskusi berbagai hal yang umum. Pada tahap inilah peneliti membangun hubungan dengan subjek yang diteliti secara jujur dan saling menukar informasi secara terbuka (bandingkan pada Bogdan dan dan Taylor, 1993). Kedua, tahap observasi secara terfokus, yakni peneliti cenderung memfokuskan pengamatannya pada topik penelitian.

Untuk mendukung tahap-tahap tersebut maka peneliti menggunakan teknik pengumpulan data, dengan cara wawancara (mendalam) dan observasi (langsung maupun tak langsung). Pengumpulan data dengan teknik wawancara (interview) digunakan peneliti untuk mendapatkan keterangan atau pendirian secara lisan dari informan. Wawancara dilakukan dengan tujuan mengumpulkan keterangan tentang pandangan hidup informan, serta pendirianpendiriannya guna membantu pelaksanaan observasi (bandingkan pada Koentjaraningrat, 1993: 129-157). Seperti diketahui bahwa metode wawancara, pada dasarnya dapat dibedakan menjadi dua golongan, yaitu: (1) wawancara berencana dan (2) wawancara tak berencana. Dalam kaitan dengan penelitian ini, peneliti menggunakan metode wawancara tak berencana yang termasuk dalam wawancara tak berstruktur tetapi tetap berfokus pada satu topik yang dibahas. Pemilihan metode wawancara ini, peneliti lakukan, karena untuk mewawancarai informan tersebut justru menghindari suasana formal, lebih dari itu wawancara peneliti lakukan bisa sampai berulang kali dan tempat wawancara pun tidak bisa direncanakan sebelumnya.

Sedangkan analisis data dalam penelitian ini lebih bersifat menggambarkan atau melukiskan keadaan subjek penelitian berdasarkan data yang telah didapatkan. Atau dengan kata lain, sifat data yang di- 
gali lebih ditekankan pada konsep emik, yakni memakai ukuran kebudayaan subjek yang sedang diteliti (lihat Creswell, 1994 dan Pelto \& Pelto, 1978:55). Sedangkan dalam analisis data, peneliti akan menguraikan secara terperinci dan bersifat kualitatif, yak-ni ditandai oleh ciri data yang berhubungan dengan kategori-kategori. Misalnya, penjabaran secara kongkret tentang siapa melakukan apa, mengapa mereka melakukannya, serta apa pengaruh dari aktivitasaktivitas dan interaksi tersebut terhadap kelangsungan usaha mereka (Vayda, 1983: 265-281).

\section{HASIL DAN PEMBAHASAN}

Kota Semarang, seperti halnya kawasan perkotaan di Indonesia dewasa ini cenderung mengalami permasalahan yang tipikal, yaitu tingginya tingkat pertumbuhan penduduk terutama akibat arus urbanisasi sehingga menyebabkan pengelolaan ruang kota semakin berat. Selain itu daya dukung lingkungan dan sosial yang ada juga menurun, sehingga tidak dapat mengimbangi kebutuhan akibat tekanan kependudukan. Permasalahan lainnya berkaitan dengan tingginya tingkat konversi lahan, terutama lahan yang seharusnya dilindungi agar tetap hijau menjadi daerah terbangun, yang menimbulkan dampak terhadap rendahnya kualitas lingkungan perkotaan. Lemahnya penegakan hukum dan penyadaran masyarakat terhadap aspek penataan ruang juga merupakan masalah seperti misalnya munculnya permukiman kumuh di bantaran sungai dan terjadinya kemacetan akibat terbaurnya lalu lintas regional dan lokal sebagai implikasi pemanfaatan ruang yang tidak sesuai dengan peruntukkannya seperti kegiatan pasar di sepanjang jalan arteri'

1 Sebagai pembanding dapat dibaca pula pada sejumlah sumber berikut:

http://hetifah.com/artikel/penyebab-gagalnyapengelolaan-pkl-di-perkotaan.html

http://www.scribd.com/doc/3499983/FormulasiKebijakan-Publik

http://ratnadwipa.blogspot.com/2008/12/agendasetting-dan-perumusan-masalah.html

http://widytaurus.wordpress.com/2008/02/15/ penggusuran-pkl-salah-siapa/

http://www.scribd.com/doc/23887284/Policy-Paper-Sanitasi-Lingkungan
Data yang ada menunjukkan bahwa jumlah penduduk perkotaan di Indonesia menunjukkan perkembangan yang cukup pesat. Pada 1980 jumlah penduduk perkotaan baru mencapai 32,8 juta jiwa atau 22,3 persen dari total penduduk nasional. Pada tahun 1990 angka tersebut meningkat menjadi 55,4 juta jiwa atau 30,9 persen, dan menjadi 90 juta jiwa atau 44 persen pada tahun 2002. Angka tersebut diperkirakan akan mencapai 150 juta atau 6o persen dari total penduduk nasional pada tahun 2015 .

Jumlah penduduk perkotaan yang terus meningkat dari waktu ke waktu tersebut akan memberikan implikasi pada tingginya tekanan terhadap pemanfaatan ruang kota, sehingga penataan ruang kawasan perkotaan perlu mendapat perhatian yang khusus, terutama yang terkait dengan penyediaan kawasan hunian, fasilitas umum dan sosial serta ruang-ruang terbuka publik di perkotaan.

Pertumbuhan penduduk yang tinggi di daerah perkotaan menimbulkan berbagai permasalahan yang rumit, karena pihak pemerintah khususnya pemerintah kota belum bisa atau lamban mengantisipasi adanya peningkatan penduduk yang cepat misalnya dengan pengadaan lahan pemukiman, kesempatan kerja, penyediaan sarana dan prasarana dan sebagainya. Seperti diketahui, Indonesia mengalami keterpurukan ekonomi yang terjadi pada tahun 1998. Krisis ekonomi tersebut mengakibatkan beban ekonomi baik masyarakat, pemerintah maupun swasta menjulang tinggi, sehingga di antaranya mengakibatkan swasta membatasi jumlah pekerjanya dengan melakukan pemutusan hubungan kerja (PHK). Beban ekonomi masyarakat yang semakin tidak terkendali mengakibatkan masyarakat tersebut mencari lapangan pekerjaan sendiri dengan terjun ke dalam sektor informal karena pemerintah tidak mampu mengatasi hal tersebut dengan menampung masyarakat korban PHK dalam sektor formal. Pilihan yang diambil oleh masyarakat tersebut salah satunya dengan menjadi PKL karena dinilai membutuhkan modal dan ketrampilan yang minim. Dengan demikian, membuka lapangan pekerjaan sendiri dengan 
menjadi PKL dianggap masyarakat sebagai solusi yang tepat walaupun omzet penjualan tidak tentu namun setidaknya dapat meringankan beban hidup.

Kurang antisipasi pemerintah dalam mengatasi perkembangan sektor informal serta ketidaksediaan lokasi yang menampung perkembangan PKL mengakibatkan PKL tersebut berlokasi di sekitar kawasankawasan fungsional perkotaan yang dianggap strategis seperti kawasan perdagangan, perkantoran, wisata, permukiman atau fasilitas-fasilitas umum. Ketidakteraturan lokasi aktivitasnya yang diakibatkan oleh bentukan fisik yang beragam dan sering terkesan asal-asalan dan kumuh berupa kioskios kecil dan gelaran dengan alas seadanya, menjadikan visual suatu kawasan perkotaan yang telah direncanakan dan dibangun dengan baik, menjadi terkesan kumuh dan tidak teratur, sehingga menurunkan citra suatu kawasan. Hingga pada akhirnya aktivitas PKL di dalam suatu perkotaan mengakibatkan menurunnya kualitas lingkungan perkotaan.

\section{PKL Sebagai Alternatif}

Seperti diketahui, Indonesia mengalami keterpurukan ekonomi yang terjadi pada tahun 1998. Krisis ekonomi tersebut mengakibatkan beban ekonomi baik masyarakat, pemerintah maupun swasta menjulang tinggi, sehingga di antaranya mengakibatkan swasta membatasi jumlah pekerjanya dengan melakukan pemutusan hubungan kerja (PHK). Beban ekonomi masyarakat yang semakin tidak terkendali mengakibatkan masyarakat tersebut mencari lapangan pekerjaan sendiri dengan terjun ke dalam sektor informal karena pemerintah tidak mampu mengatasi hal tersebut dengan menampung masyarakat korban PHK dalam sektor formal. Pilihan yang diambil oleh masyarakat tersebut salah satunya dengan menjadi PKL karena dinilai membutuhkan modal dan ketrampilan yang minim. Dengan demikian, membuka lapangan pekerjaan sendiri dengan menjadi PKL dianggap masyarakat sebagai solusi yang tepat walaupun omzet penjualan tidak tentu namun setidaknya dapat meringankan beban hidup.
Kurang antisipasi pemerintah dalam mengatasi perkembangan sektor informal serta ketidaksediaan lokasi yang menampung perkembangan PKL mengakibatkan PKL tersebut berlokasi di sekitar kawasankawasan fungsional perkotaan yang dianggap strategis seperti kawasan perdagangan, perkantoran, wisata, permukiman atau fasilitas-fasilitas umum. Ketidakteraturan lokasi aktivitasnya yang diakibatkan oleh bentukan fisik yang beragam dan sering terkesan asal-asalan dan kumuh berupa kioskios kecil dan gelaran dengan alas seadanya, menjadikan visual suatu kawasan perkotaan yang telah direncanakan dan dibangun dengan baik, menjadi terkesan kumuh dan tidak teratur, sehingga menurunkan citra suatu kawasan. Hingga pada akhirnya aktivitas PKL di dalam suatu perkotaan mengakibatkan menurunnya kualitas lingkungan perkotaan.

Terkait dengan permasalahan tersebut, pemerintah sudah mencari alternatif pemecahannya dengan jalan menertibkan dengan menggusur atau menata aktivitas PKL dengan mengembalikan fungsi asli kawasan tersebut serta merelokasi para PKL tersebut ke lokasi baru. Namun pada kenyataannya, setelah pelaksanaan relokasi dengan penertiban dan penggusuran PKL yang terkadang disertai dengan tindakan pemaksaan dari petugas ketertiban kembali beraktivitas ke lokasi semula bahkan jumlahnya bertambah.

Era reformasi yang diawali dengan krisis ekonomi yang berkepanjangan, mengakibatkan banyaknya pengangguran. Di samping mereka yang sulit mencari pekerjaan, sampai kepada buruh atau karyawan yang terpaksa berhenti kerja karena mengalami PHK dari perusahaan tempat mereka bekerja. Perusahaan-perusahan banyak yang mengurangi tenaga kerjanya, karena produksi berkurang dan aktivitas perusahaan menurun.

Tidak ada cara lain bagi mereka yang bermodal kecil, selain menciptakan lapangan kerja serba cepat dan instan. PKL adalah cara yang dianggap paling tepat. Dengan modal seadanya dan mendapatkan barang dagangan yang dinilai cepat laku, dijual juga 
dengan untung sekedarnya. Pokoknya dari untung yang tidak banyak itu, istilahnya dapat untuk sekedar menyambung hidup. Ada selogan dan prinsip yang selalu menjadi landasan berpijak PKL, yakni: daripada berbuat kejahatan dan dosa, tentu lebih baik melakukan pekerjaan yang hina tetapi halal.

Hal tersebut terjadi di Kota Semarang, seperti di kota-kota besar Indonesia lainnya. Fenomena dualistik perkotaan khususnya terkait dengan sektor formal dan informal telah menjadi permasalahan tersendiri dalam penanganannya. Perkembangan sektor informal pun seolah tidak mau kalah dengan sektor formal yang seakan membentuk hubungan simbiosis di antara keduanya (bandingkan pada Surya dan Widjajanti, 2007). Memang, tidak ada satupun kota di dunia ini yang tidak mempunyai PKL. Bukan hanya di negara miskin, seperti di Asia dan Afrika, tetapi PKL juga ada di kota-kota negara maju Amerika dan Eropa. PKL bahkan di kota tertentu dijadikan kebanggaan dan menjadi obyek wisata. Para turis yang berkunjung ke suatu kota, masih belum lengkap pelancongannya apabila ia tidak singgah dan menikmati suguhan PKL. Biasanya, barang-barang di PKL itu menarik, unik, sederhana dan murah. Sehingga, banyak yang dijadikan sebagai cinderamata atau souvenir. Demikian pula, kalau jenis jualan itu makanan, biasanya banyak juga masakan khas dan tradisional.

Bagi Kota Semarang, keberadaan PKL ada di mana-mana, baik di seluruh jalur jalan dan tempat-tempat terbuka, maupun lahan kosong kota ditempati PKL. Di kota ini, PKL dibagi adalah dua jenis: legal dan ilegal atau sah dan liar. PKL yang dianggap sah, adalah PKL yang menempati lahan yang mendapat persetujuan dari "yang berwenang". Pengertian yang berwenang ini macam-macam, mulai dari perorangan sebagai pemilik lahan, sampai tingkat pengurus RT, RW, aparat kelurahan, kecamatan sampai tingkat Pemerintah Kota (Pemkot) Semarang. Sehingga para PKL yang dianggap sah atau legal itu, disebut sebagai PKL binaan, sedangkan yang tidak termasuk katagori ini

Tabel 1. Jumlah PKL Kota Semarang berdasarkan kecamatan Menurut keadaan pada Bulan Maret 2010

\begin{tabular}{rlccc}
\hline No. & Nama Kecamatan & Jml kelurahan & Jml PKL & Prosentase \\
\hline 1 & Semarang Tengah & 15 & 1742 & $23,99 \%$ \\
2 & Semarang Selatan & 10 & 912 & $12,56 \%$ \\
3 & Semarang Timur & 10 & 817 & $11,25 \%$ \\
4 & Semarang Utara & 9 & 749 & $10,31 \%$ \\
5 & Semarang Barat & 16 & 627 & $8,63 \%$ \\
6 & Gayamsari & 7 & 589 & $8,11 \%$ \\
7 & Pedurungan & 12 & 398 & $5,48 \%$ \\
8 & Candisari & 7 & 369 & $5,08 \%$ \\
9 & Gajah Mungkur & 8 & 270 & $3,72 \%$ \\
10 & Banyumanik & 11 & 220 & $3,03 \%$ \\
11 & Tembalang & 12 & 200 & $2,75 \%$ \\
12 & Tugu & 7 & 129 & $1,78 \%$ \\
13 & Genuk & 13 & 118 & $1,62 \%$ \\
14 & Gunungpati & 16 & 102 & $1,40 \%$ \\
15 & Mijen & 14 & 20 & $0,28 \%$ \\
16 & Ngaliyan & 10 & 0 & $0,00 \%$ \\
\hline & & 177 & 7262 & $100,00 \%$ \\
\hline
\end{tabular}

Sumber: Diolah penelitian lapangan bulan Januari-Maret 2010 
adalah PKL ilegal atau liar².

Bertolak dari sejumlah penjelasan tersebut, dapat dideskripsikan tentang PKL di kota ini secara umum, yang antara lain menyangkut dua hal: (1) jumlah PKL di Kota Semarang dan peraturan yang memayungi PKL dan (2) Alasan menjadi PKL dan strategi yang dikembangkan untuk menjalankan usahanya. Berdasarkan hasil penelitian lapangan bahwa jumlah pedagang kaki lima berdasarkan hasil pendataan pada 16 kecamatan dan 177 kelurahan di Kota Semarang adalah sebesar 7262 PKL. Hal tersebut dapat dilihat pada Tabel 1.

Di Kota Semarang ada beberapa pusatpusat PKL yang sangat ramai, seperti lokasi kawasan Basudewo, Brotojoyo, Kaligarang, jalan Kartini dan Taman Progo. Keberadaan pedagang-pedagang kaki lima tersebut berada pada daerah larangan dagang seperti di trotoar, tepi jalan raya, bahu jalan dan bantaran sungai.

\section{Pilihan dan Hubungan Patron-Klien}

Sejumlah peneliti menyebutkan bahwa menekuni usaha sebagai PKL tidak membutuhkan pendidikan yang terlalu tinggi. Jika latar belakang pendidikan tidak menjadi persyaratan utama, maka sebenarnya pekerjaan sebagai pedagang kaki lima bisa dilakukan oleh siapa saja. Jika pekerjaan sebagai pedagang kaki lima bisa dilakukan oleh siapa saja, maka para urbanis dari desa yang berlatar belakang petani pun bisa menekuni usaha pedagang kaki lima (bandingkan pada Ali, 1989, Bairoh, 1973, Breman, 1980, dan Latief, 1977).

Pengalaman informan Sami (64 tahun), berawal ketika ia pensiunan dari pekerjaannya sebagai salah satu staff di DPU Kota Semarang, Sami mencoba untuk menggeluti profesi baru sebagai petani. Ia menggarap sawah warisan orangtuanya di Solo. Pekerjaan ini dilakoninya selama kurang lebih tiga tahun. Pada awal-awal sebagai petani, hasil yang diperolehnya sangat

2 Sebagai pembanding dapat dibaca pada http://www.vhrmedia.com/PKL-Semarang-Tolak-Penggusuran-berita2493.html) lumayan. Hal ini menyebabkan Sami semakin bersemangat untuk menggeluti profesi barunya itu. Tetapi ketika terjadi peristiwa kekeringan yang melanda desanya, hasil panennya merosot drastis. Peristiwa ini terulang sampai tiga kali musin tanam sampai akhirnya ia kehabisan modal sehingga tidak bisa membeli benih dan pupuk. Akhirnya ia menghentikan kegiatannya sebagai petani dan beralih profesi sebagai PKL yang menjajakan alat-alat otomotif.

Lebih dari itu, berusaha sebagai PKL biasanya tidak membutuhkan modal yang terlalu besar. Jika mengembangkan usaha PKL tidak membutuhkan modal besar, maka dengan kemampuan modal keuangan sendiri atau bantuan keluarga dapat mendorong seseorang menjadi PKL . Jika seseorang membuka usaha sebagai PKL hanya dengan modal sendiri, maka keberadaan PKL bisa disikapi sebagai jenis usaha yang mandiri. Jika seseorang membuka usaha PKL dengan modal bantuan keluarga, maka resiko kerugian serta pengembangan usaha akan ditanggung bersama anggota keluarga tersebut. Jika resiko kerugian serta pengembangan usaha akan ditanggung bersama anggota keluarga, maka masing-masing anggota keluarga yang menekuni pekerjaan PKL akan berusaha mengembangkan strategi bersama (bandingkan pada Ernawati, 1995, Jamuin, 2000, dan Suharyanti.dkk, 1995).

Pengalaman informan Kecek (37 tahun). Berawal saat dia hanya iseng-iseng membawa barang barang bekas yang dia kumpulkan di rumahnya. Saat dibawa ke PKL Poncowolo, beliau langsung dikerubungi banyak PKL yang ingin membelinya, ternyata barang yang dia bawa laris dan sudah ludes terjual dalam waktu singkat. Seminggu setelah itu Pak Kecek mulai mencoba membawa alas dan menjajakan barang bekasnya di trotoar, hasil yang dia dapat tergolong lumayan. Akhirnya mulai saat itu, Kecek memulai usaha barunya sebagai seorang pedagang PKL yang menjual barang bekas.

Berdasarkan hasil observasi dan wawancara dengan informan pendapatan sebagai PKL ternyata jauh lebih besar di- 
bandingkan dengan pendapatan di sektor formal, atau bahkan pendapatan ketika masih sebagai petani di desa. Seperti yang diungkapkan informan Safrudin (23), salah seorang PKL yang menjual jalan Kokrosono Semarang yang kini juga memiliki tabungan di BRI sebesar Rp 10 juta:

"Selain itu, kami masih bisa mengirim uang setiap bulan $\mathrm{Rp} 250$ ribu ke kampung halaman. Bahkan, meskipun kecil kami juga sudah membeli sebidang sawah di desa. Dibandingkan teman saya, yang juga tamat SLTA, dan sekarang bekerja sudah lima tahun lebih di Pemda Semarang, tetapi gajinya hanya $\mathrm{Rp} \mathrm{1,3}$ juta. Itu belum termasuk uang untuk bayar kontrak kamar, mencicil kendaraan, serta kebutuhan makan sehari-hari. Alhamdulilah, pendapatan saya bersih, setelah dipotong untuk bayar kontrak rumah, makan, dan belanja sehari-hari setiap bulan rata-rata bisa mencapai sekitar Rp 1 juta”.

Maka, para petani yang kemudian meninggalkan dunia pertanian statis itu berusaha berkerja di kota dan menekuni sektor informal, sebenarnya merupakan pilihan yang paling rasional untuk mengatasi kemiskinan di pedesaan. Apalagi -- seperti juga yang telah diungkapkan pada bagian sebelumnya -- sektor informal lebih berciri padat karya, tidak menuntut jenjang pendidikan yang terlalu tinggi, lebih mudah untuk keluar masuk menekuni bidang usaha tertentu, serta dapat dilakukan dari ruang lingkup keluarga. Bahkan, betapa pun kecilnya pendapatan yang diperoleh dari sektor informal di perkotaan, kesempatan kerja di kota (seperti Kota Semarang) dianggap jauh lebih baik daripada lapisan berpendapatan rendah di pedesaan.

Sejalan dengan itu, informan yang menjadi subjek penelitian ini juga memberi alasan bahwa pilihannya berkerja menjadi PKL di Kota Semarang, disebabkan di desanya tidak ada lagi jenis pekerjaan yang harus dikembangkan. Meskipun di desanya dia bisa bekerja di bidang pertanian namun dia tidak tertarik, karena dianggapnya kurang memberi peluang untuk berkembang maju3. Bahkan, informan juga telah mencoba untuk bekerja di sektor formal (kantor percetakan di Tegal), tetapi dianggap tidak mampu mengakomodasi keinginan untuk mendapatkan penghasilan yang layak.

Bertolak dari pernyataan tersebut, pada dasarnya mengembangkan usaha sebagai PKL dianggap mempunyai nilai strategis, sementara ketika mereka harus berhadapan dengan resiko usaha - seperti menghadapi operasi penertiban - akan dicari sejumlah strategi oleh masing-masing pelaku tindakan sosial tersebut.

Untuk melihat beberapa strategi yang dikembangkan para PKL ketika memulai dan menjaga kelangsungan profesinya dapat diperhatikan beberapa pengalaman informan sebagai berikut. Informan Mbah Bibit (67 tahun) misalnya, menekuni pekerjaannya sebagai PKL di lokasi pedagang kaki lima Kokrosono Semarang berkisar kurang lebih 12 tahun (1998 - 2010). Pada awalawal berdagang dia membeli dagangannya langsung datang ke Kartosuro. Hal itu dilakukan karena selain fisiknya masih kuat, ia akan memperoleh keuntungan yang lebih banyak. Akhir-akhir ini, untuk membeli dagangan dia lebih memilih diantar langsung oleh pemasok langganannya dari Kartosuro. Dia berdagang dengan menggunakan gerobak. Dagangannya pernah sekali dirazia oleh satpol PP, beruntung barang dagangannya dimasukkan ke karung dan segera di bawa pergi, tetapi gerobak beliu berhasil di sita satpol PP.

Yang dilakukan Mbah Bibit menunjukkan salah satu strategi untuk menyiasati sejumlah aturan main yang ada. Berbeda dengan pengalaman informan Sami (64 tahun) yang berdagang alat-alat bengkel di jalan Brotojoyo Semarang. Ketika Satpol PP datang melakukan razia, ia segera menyebe-

3 Bandingkan dengan sejumlah penelitian terdahulu menyebutkan bahwa mencari pekerjaan yang sesuai dengan keahliannya amatlah sulit. Selain itu, lahan pertanian yang dimiliki keluarga di desa tidak memungkinkan menghasilkan keuntungan secara memadai untuk seluruh anggota keluarga (lihat Ali, 1989; Hatta, 1992; dan Reuyeuk, 1993) 
rangkan barang dagangannya ke jalan sebelah dengan alasan di Kelurahan Pindrikan diperbolehkan untuk berjualan sedangkan kelurahan Bulu dilarang untuk berjualan.

Lain dengan Mbah Bibit dan Sami, Kecek (37 tahun) yang berdagang barangbarang bekas dalam menjalankan strategi untuk menyiasati sejumlah aturan. Selama menggeluti usaha sebagai pedagang kaki lima dia pernah sekali tertangkap satpol PP. Peristiwa ini terjadi pada tahun 2002. Proses pengambilan barang yang disita menunggu waktu yang dijadwalkan satpol PP. Untuk mengambil kembali barang yang disita, dia harus menyerahkan foto copy KTP, membeli formulir seharga Rp 10.00o,- dan menandatangani surat perjanjian dengan materai seharga Rp 6.00o,-. Sehingga jadi total pengeluaran keseluruhan saat mengambil gerobak adalah Rp 16.ooo,-. Biaya itu bisa saja bertambah bila di lapangan tersebut ada calo atau preman yang meminta jatah keamanan.

Bertolak dari gambaran tersebut dapat dikatakan bahwa menekuni profesi PKL sebenarnya bukan tujuan yang mereka idamkan sejak semula. Dari data yang diperoleh di lapangan mengungkapkan bahwa latar belakang sebelum menekuni profesi PKL mayoritas adalah petani yang gagal mengembangkan dunia pertanian kemudian migrasi ke kota yang kemudian menekuni profesi PKL. Kendati bukan merupakan tujuan semua, namun untuk menekuni profesi di bidang PKL harus melalui proses, di antaranya melalui proses magang. Proses magang inilah yang kemudian menandai perkembangan usaha di bidang PKL.

Dengan elastisitas yang terdapat pada sektor informal, kemudian lebih memberi ruang untuk keluar masuk menekuni bidang usaha tertentu, mengakibatkan sektor ini banyak menarik minat sejumlah orang. Akan tetapi, berdasarkan hasil observasi dan wawancara dengan informan, proses keberhasilan menekuni sektor informal justru harus melalui berapa tahap. Seperti yang diungkapkan informan bahwa daya tarik untuk menekuni sektor informal, bertolak dari keberhasilan yang telah dirasakan figur dalam lingkungan keluarga sebelumnya ${ }^{4}$. Disebutkan, keberhasilan kakaknya yang telah lebih dahulu menekuni sektor tersebut mendorongnya untuk mengikutinya, meskipun harus dimulai dengan menjadi pembantu (kenek) kakak-kakaknya. Dengan menjadi kenek, berarti merupakan proses belajar yang paling mudah dilakukan untuk mengembangkan usaha lebih lanjut, baik menyangkut pemilihan jenis usaha, modal yang dibelanjakan, segmen pasar yang akan dijadikan sasaran, maupun kadar resiko yang bakal dihadapi.

Selain itu, dalam mengembangkan usaha tersebut peran keluarga juga menentukan pola usaha PKL. Peran keluarga sangat menentukan tumbuh dan berkembangnya seseorang dalam menekuni sektor informal. Peran keluarga ini tidak hanya menyangkut proses belajar menekuni dalam menekuni sektor informal semata, tetapi juga bertanggung jawab terhadap penentuan segmen pasar yang akan dijadikan sasaran, serta cara menghadapi resiko yang bakal terjadi. Apalagi dalam keluarga Jawa - seperti juga merupakan latar belakang informan - tingkat kesenioran akan menentukan hak dan kewajiban seseorang untuk ikut terlibat dengan persoalan yang dihadapi saudarasaudara yang lain dalam satu keluarga (bandingkan pada Geertz, 1985).

Informan yang menjadi subjek penelitian ini, Safrudin (23 th) adalah anak keempat dari delapan saudara dari pasangan M.Naib dan Nur Janah telah mengikuti jejak kakak-kakaknya untuk menekuni sektor informal, menjadi penjual nasi goreng. Sejak dari pilihan menekuni pekerjaan, proses belajar, penentuan lokasi usaha, dukungan modal, serta aturan main dalam pembagian hasil usaha ditentukan oleh keluarga mere-

4 Seperti hasil penelitian sebelumnya menyebutkan bahwa peran keluarga sangat menentukan jenis pekerjaan yang dipilih. Bahkan, dengan melihat peran keluarga dalam menentukan jenis pekerjaan ini, maka tanggung jawab setiap anggota keluarga untuk mengembangkan pekerjaan tersebut lebih terlihat (bandingkan pada Mutmainah, 1993; Saleh, 1995; Lubis, 1998; Susilowati, 1997; dan Tantu 1992). 
$k a^{5}$.

Konsekuensi dari dukungan modal keluarga tersebut, menurut informan, masingmasing anggota keluarga yang telah berhasil menekuni usahanya akan menyumbang untuk kas keluarga dalam setiap bulannya sebesar Rp 250 ribu. Uang tersebut selain akan digunakan untuk keperluan seperti bantuan permodalan bagi yang akan memulai usaha, atau juga untuk kebutuhan keluarga yang masih tinggal di desa. Dengan demikian, semakin banyak anggota keluarga yang terjun dalam sektor informal, maka akan semakin besar mendukung perekonomian keluarga.

Informan Safrudin memberi contoh keberhasilan warung yang dimiliki kakak tertua, yang berjumlah empat buah, yang kini lebih dikelola oleh sanak familinya yang juga menjadi anak buah kakaknya tersebut. Setiap bulan kakaknya menerima setoran dari keempat warung masing-masing $\mathrm{Rp} 1$ juta. Kakak Safrudin setiap bulan menerima bersih sekitar Rp 4 juta. Yang mengelola sekarang juga untung karena tidak perlu mengeluarkan modal tinggal meneruskan. Akan tetapi, menurut informan Safrudin, aturan itu tidak terlalu kaku diterapkan. Misalnya, jika setiap warung tersebut sebulan hanya menghasilkan keuntungan sebesar Rp 1,5 juta. Paling-paling kakaknya hanya meminta $\mathrm{Rp} 800$ ribu saja. Sisanya untuk berjaga-jaga tambahan modal. Selain itu, kakak saya juga harus mengeluarkan uang Rp 250 untuk setiap warungnya, sebagai uang kas keluarga. Kalau punya 4 warung berarti dia mengeluarkan Rp 1 juta. Bandingkan pula dengan temuan peneliti sebelumnya yang menyebutkan bahwa pemanfaatan keuntungan para pedagang kaki lima, biasanya lebih diinvestasikan pada pengembangan usaha, atau untuk menambah kekayaan keluarga di kampung hala-

5 Bandingkan dengan sejumlah penelitian yang terdahulu bahwa sejumlah strategi harus dilakukan untuk menentukan pekerjaan tersebut, baik mulai memilih lokasi hingga permodalan yang harus dikeluarkan, merupakan tanggung jawab keluarga besar (lihat Ali, 1989; Ernawati, 1995; Latief, 1977; Ngatno, 1996; dan Suhariyanti, dkk., 1995) man.

PKL, sering disebut sebagai wiraswatawan yang independen, berusaha sendiri, keberhasilannya akan diukur pada kemampuan untuk menarik pelanggan. Pendapat tersebut tidak sepenuhnya dapat dibenarkan, karena usaha di sektor informal tersebut pada dasarnya juga memiliki ketergantungan dengan pihak lain yang mendukung kelangsungan usaha tersebut (bandingkan pada Bromkey, 1978). Akibat dari ketergantungan tersebut maka PKL pun akan berusaha untuk menjalin hubungan dan jaringan dengan pihak lain, sebagai bagian dari strategi adaptif mempertahankan usahanya.

Tak berbeda dengan yang diungkapkan informan penelitian ini, untuk mempertahankan usahanya tidak jarang pedagang kaki lima akan tergantung dengan pihak lain. Bahkan, secara tidak sadar mereka juga telah membangun hubungan patronklien terhadap pihak-pihak tertentu, demi mempertahankan kelangsungan usahanya ${ }^{6}$. Pengertian membangun patron-kilen, menurut informan, lebih berupa menjalin hubungan baik dengan pihak-pihak tertentu yang kemudian membantu usahanya. Seperti yang dilakukan informan Safrudin, ketika harus membeli bahan-bahan mentah untuk memenuhi usahanya tak jarang dia harus hutang dengan pemilik warung penjual bahan-bahan tersebut di pasar. Informan bisa hutang dengan pemilik warung di pasar, tentu saja karena tingkat kepercayaan yang dibangun melalui hubungan patronklien tersebut. "Misalnya, saya belanja habis 100 ribu rupiah, bisa dicicil hingga sepuluh kali. Soalnya saya kan sudah langganan”. Cara membangun hubungan patron-klien ini, merupakan strategi adaptif yang dilakukan PKL.

6 Membangun hubungan patron-klien ini juga telah diungkapkan beberapa peneliti sebelumnya para pedagang kaki lima ini juga menjalin hubungan patron-klien, tidak hanya pada pedagang bahan mentah yang dijadikan langganannya, tetapi juga menyangkut peran serta pemerintah dalam menciptakan suasana usaha yang lebih kondusif (bandingkan dengan Lukman 1995; Munir 1993; dan Saleh, 1995). 
Berdasarkan temuan yang telah dilakukan sejumlah peneliti sebelumnya, menyebutkan bahwa strategi adaptif yang dilakukan pedagang kaki lima telah dilakukan sejak mereka memulai usaha hingga ketika mempertahankan kelangsungan usaha tersebut. Sejak memulai usaha misalnya, para pedagang kaki lima akan memilih lokasi yang strategis untuk berusaha dan sekaligus nyaman untuk berusaha. Lebih dari itu, kestrategisan juga masih akan ditopang dengan sejumlah usaha agar barang dagangannya dibeli pelanggan.

Sedangkan menyangkut strategi menghadapi operasi ketertiban yang dilakukan Satpol PP dapat diperhatikan pengalaman yang diungkapkan informan Napani (45 tahun) berikut ini.

Jam 8.30 pagi, ketika Napani, 48 tahun, mendorong gerobag sotonya. Pagi itu, seperti biasa dia sedang memulai membuka dagangannya di bantaran sungai Banjir Kanal Timur. Bantaran sungai tempat biasa dia mendasarkan dagangannya. Waktu itu belum banyak orang di sana. Ketika dia sedang beranjak meninggalkan gerobag untuk mengambil air, tiba-tiba serombongan petugas Satpol PP Kota Semarang datang. Tanpa sepatah kata pun gerobag yang penuh makanan itu diangkut ke mobil operasi. "Saya hanya bisa diam, tak mampu mempertahankan, selain memegang ember ini", katanya. Teman-teman lain yang kebetulan belum mendirikan dagangannya juga tampak hanya membisu menyaksikan operasi tersebut.

"Waktu yang saya pikirkan adalah bagaimana menarik kembali gerobak yang telah diangkut petugas tersebut. Karena di kantong saya tak ada uang sepeser pun untuk menebus gerobag tersebut", ujarnya. Atas kebaikan teman-temannya maka terkumpullah uang sebanyak Rp 250 ribu untuk menebus gerobag tersebut. Maka setelah terkumpul uang tebusan tersebut, pada siang harinya Napani berangkat ke kantor Satpol PP. Dia melihat gerobagnya teronggok bersama gerobag-gerobag lain hasil operasi. "Makanan yang tadi penuh, ternyata waktu itu telah ludes entah siapa yang menghabiskan makan begitu banyak itu. Tapi tak apalah, yang penting saya bisa menarik kembali gerobag ter- sebut, " katanya datar. Uang tebusan pun dia berikan kepada kepala seksi operasi penertiban, dan setelah mendapatkan basa-basi nasihat, dia mendorong gerobagnya ke rumahnya. Dan, esoknya dia kembali mengoperasikan barang dagangannya dengan gerobag tersebut dan masih di tempat semula.

Gambaran dari temuan di lapangan itu, menyiratkan tentang fenomena-fenomena empirik yang pada dasarnya akan selalu menjadi salah satu bentuk tindakan sosial setiap pedagang kaki lima. Mereka akan terus mempertahankan usahanya sebagai PKL dan mempertahankan lokasi usaha, karena pekerjaan dan lokasi tersebut dianggap berkait dalam mengembangkan keuntungan secara ekonomi.

Apalagi, selain memberi keuntungan tindakan sosial setiap PKL mempertahankan usahanya juga karena usaha tersebut merupakan salah satu usaha yang tidak permanen. Jika PKL merupakan usaha yang tidak permanen, maka sewaktu-waktu pekerjaan itu jika tidak menguntungkan secara ekonomis akan mudah ditinggalkan atau berganti usaha lain. Akan tetapi, jika pekerjaan itu menguntungan secara ekonomis, maka sejumlah resiko akan dihadapi demi mengembangkan usaha tersebut. Jika sejumlah resiko akan dihadapi demi mengembangkan usaha tersebut, maka dibutuhkan sejumlah strategi bagi para pedagang kaki lima dalam mengatasi resiko tersebut.

Lebih dari itu, berusaha sebagai PKL biasanya tidak membutuhkan modal yang terlalu besar. Jika mengembangkan usaha pedagang kaki lima tidak membutuhkan modal besar, maka dengan kemampuan modal keuangan sendiri atau bantuan keluarga dapat mendorong seseorang menjadi pedagang kaki lima. Jika seseorang membuka usaha sebagai PKL hanya dengan modal sendiri, maka keberadaan PKL sebenarnya keberadaan pedagang kaki lima bisa disikapi sebagai jenis usaha yang mandiri.

Jika seseorang membuka usaha sebagai PKL dengan modal bantuan keluarga, maka resiko kerugian serta pengembangan usaha akan ditanggung bersama anggota 
keluarga tersebut. Jika resiko kerugian serta pengembangan usaha akan ditanggung bersama anggota keluarga, maka masingmasing anggota keluarga yang menekuni pekerjaan PKL akan berusaha mengembangkan strategi bersama (bandingkan pada Ernawati, 1995; Jamuin, 2000; dan Suharyanti.dkk, 1995). Bertolak dari pernyataan tersebut, pada dasarnya mengembangkan usaha sebagai PKL dianggap mempunyai nilai strategis, sementara ketika mereka harus berhadapan dengan resiko usaha seperti menghadapi operasi penertiban - akan dicari akan dicari sejumlah strategi oleh masing-masing pelaku tindakan sosial tersebut.

\section{Konsep Jaringan Sosial dan Strategi Adaptasi}

Pada dasarnya tindakan sosial terjadi dari interaksi-interaksi konkret yang melibatkan subjek pelaku untuk melakukan respons terhadap aturan-aturan (rules) yang ada. Apalagi, setiap manusia berelasi dengan sesamanya dalam rangka membagi makna, maka tindakannya akan bertolak dari peranannya sebagai orang per orang atau subjek bebas dengan segenap motif dan instrumen pembentuk maknanya sendiri. Subjek pelaku bebas merespons terhadap segala yang tampak (seeming) dan mengartikan gejalagejala (being) atau juga memaknai segala kebenaran itu sendiri. Gambaran itu, salah satu di antaranya dapat dilihat pada relasi face to face atau perjumpaan dalam kehidupan sosial sehari-hari. Dengan demikian, tindakan sosial dapat dipahami lebih pada bagaimana orang menciptakan dan mempergunakan makna-makna, ketimbang bagaimana petunjuk, norma, dan nilai-nilai kultural menyediakan penjelasan-penjelasan atas makna tindakan sosial tersebut (bandingkan pada Blumer, 1969, Goffman, 1974:247-300); dan Sutrisno, 2003:64).

Para penganut interaksionisme simbolik menyadari keberadaan adat kebiasaan, peran-peran, dan institusi-institusi sosial, yang membentuk aturan-aturan sosial. Tetapi, menurut mereka, keberadaan aturan-aturan sosial itu pada taraf tertentu akan kabur dan tidak mampu memerinci segala aturan-aturan sosial itu sendiri. Aturan-aturan sosial tersebut hanya merupakan kerangka kerja, yang memberi ruang setiap individu untuk berinteraksi dan menghadapi persoalan-persoalan yang ada. Interaksionisme simbolik percaya bahwa manusia ingin menciptakan penafsiran mereka sendiri tentang sebuah kenyataan sosial akibat dari interaksi-interaksi sebelumnya. Atas dasar penafsiran itulah, manusia masuk ke dalam jenis-jenis hubungan-hubungan sosial tertentu. Inilah sebuah kegiatan antarpribadi. Dari kegiatan antar-pribadi tersebut muncullah konsensus dalam kadar tertentu mengenai "apa yang sedang terjadi" dan "siapa yang memainkan peran" tertentu dalam "drama" itu. Kegiatan ini tidak harus menghasilkan persetujuan, karena setiap "diri" memiliki pandangannya sendiri mengenai sesuatu yang sedang terjadi (bandingkan pada Blumer, 1969).

Setiap individu, melihat kenyataan sosial adalah suatu fakta objektif yang harus diperhitungkan dengan sikap-sikap dan kepercayaan-kepercayaan orang lain. Setiap individu harus menginterpretasikan sikap-sikap itu agar dapat melaksanakan hubungan-hubungan rutin dengan orang lain. Tetapi, setiap individu tidak perlu sama sekali menerima pandangan-pandangan orang lain, kerena ia bukan bagian dari hubungan-hubungan yang membentuk penafsiran-penafsiran standar tentang kenyataan sosial. Makna-makna sosial adalah hasil-hasil kelompok yang dialami bersama secara luas yang dicapai dengan kerja sama melalui seleksi atas ciri-ciri dunia eksternal yang dapat dianggap bermakna. Bertolak dari kenyataan tersebut maka ruang spontanitas individu, cukup membuat metafor yang sesuai untuk kehidupan sosial yaitu merupakan sebuah permainan (game) daripada sekadar main-main (plays). Para individu bebas bertindak dan bekerja sama dalam aturan-aturan yang longgar. Mereka tidak harus membuat garis-garis yang pasti atau sikap-sikap yang telah ditentukan sebelumnya, karena sebagai subjek pelaku manusia senantiasa dapat menaklukkan sistem yang dibuat untuk memagari tindakan sosialnya (Blumer, 1969; Goffman, 1974; dan 
Mead, 1934).

Kendati begitu, harus diakui bahwa aturan-aturan dan norma-norma itu justru seringkali "dilawan" oleh subjek pelaku secara aktif, kreatif, bahkan manipulatif dalam menghadapi lingkungannya yang terekspresi dalam tindakan sosialnya. Dengan demikian, tindakan sosial subjek pelaku, di satu sisi bisa menciptakan sistem sosial, tetapi sisi lain juga melawan sistem sosial yang telah tercipta sebelumnya. Hal itu terjadi, karena sebagai subjek pelaku (manusia) senantiasa berusaha untuk memanipulasi keteraturan normatif. Sejalan dengan hal itu, dalam kehidupan sehari-hari terdapat gambaran perbenturan dan saling tarik menarik antara aturan-aturan normatif dengan pragmatik, norma dengan tindakan, serta ide dengan tindakan sosial (bandingkan pada Bailey dalam Saifuddin, 2005: 175-180). Perbenturan dan tarik menarik antara aturanaturan normatif dengan pragmatik, norma dengan tindakan, serta ide dengan tindakan sosial itulah yang kemudian menjadi bahan diskusi dan ranah kajian ini.

Implikasi atas peran sentral subjek pelaku dalam pendekatan interaksionisme simbolik tersebut pada dasarnya memuat sejumlah perspektif. Misalnya, perhatian khusus pada manusia yang memanfaatkan ruang sosial melalui membaca situasi dan berinteraksi dapat membangun diskusi tentang situasi dan konteks perilaku dalam merespons "arena" permainan sosial. Selain itu, memberi implikasi pula pada hubungan antara makna (situasi) dan pelaku subjek yang terekspresi melalui aksi, pemberian arti, dan representasi diri dari identitas masing-masing individu. Dari sinilah terlihat adanya peran semiotika dalam interaksi (verbal), karena masing-masing subjek pelaku mengartikan konteks dan situasi secara berbeda-beda. Di sisi lain sejumlah situasi dan konteks tersebut memuat aspek ritual dalam institusi-institusi sosial yang agak mengarah pada elaborasi dalam tradisi Durkheimian (bandingkan pada Astono dan Soembogo, 2005: 73-85).

Sejumlah tindakan sosial manusia, khususnya yang dilakukan para PKL seperti temuan di lapangan dalam penelitian ini, menyiratkan tentang tindakan sosial manusia yang kemudian mengkonstruksi konsep jaringan sosial dan strategi adaptasi PKL Kota Semarang. Mereka akan terus mempertahankan usahanya sebagai PKL dan mempertahankan lokasi usaha, karena pekerjaan dan lokasi tersebut dianggap berkait dalam mengembangkan keuntungan secara ekonomi.

Apalagi, selain memberi keuntungan tindakan sosial setiap PKL mempertahankan usahanya juga karena usaha tersebut merupakan salah satu usaha yang tidak permanen. Jika PKL merupakan usaha yang tidak permanen, maka sewaktu-waktu pekerjaan itu jika tidak menguntungkan secara ekonomis akan mudah ditinggalkan atau berganti usaha lain. Akan tetapi, jika pekerjaan itu menguntungan secara ekonomis, maka sejumlah resiko akan dihadapi demi mengembangkan usaha tersebut. Jika sejumlah resiko akan dihadapi demi mengembangkan usaha tersebut, maka dibutuhkan sejumlah strategi bagi para PKL dalam mengatasi resiko tersebut (bandingkan pada Broomley, 1978; Lukman, 1995; Munir, 1993; dan Saleh, 1995).

Di lain pihak, disebutkan oleh sejumlah peneliti bahwa menekuni usaha sebagai PKL tidak membutuhkan pendidikan yang terlalu tinggi. Jika latar belakang pendidikan tidak menjadi persyaratan utama, maka sebenarnya pekerjaan sebagai PKL bisa dilakukan oleh siapa saja. Jika pekerjaan sebagai PKL bisa dilakukan oleh siapa saja, maka para urbanis dari desa yang berlatar belakang petani pun bisa menekuni usaha PKL (bandingkan pada Ali, 1989; Bairoh, 1973; Breman, 1980; dan Latief, 1977).

Lebih dari itu, berusaha sebagai PKL biasanya tidak membutuhkan modal yang terlalu besar. Jika mengembangkan usaha PKL tidak membutuhkan modal besar, maka dengan kemampuan modal keuangan sendiri atau bantuan keluarga dapat mendorong seseorang menjadi PKL. Jika seseorang membuka usaha sebagai PKL hanya dengan modal sendiri, maka keberadaan PKL sebenarnya keberadaannya bisa disikapi sebagai jenis usaha yang mandiri. Jika seseorang membuka usaha sebagai PKL 
dengan modal bantuan keluarga, maka resiko kerugian serta pengembangan usaha akan ditanggung bersama anggota keluarga tersebut. Jika resiko kerugian serta pengembangan usaha akan ditanggung bersama anggota keluarga, maka masing-masing anggota keluarga yang menekuni pekerjaan pedagang kaki lima akan berusaha mengembangkan strategi bersama (bandingkan pada Ernawati, 1995; Jamuin, 2000; dan Suharyanti.dkk, 1995).

Bertolak dari pernyataan tersebut, pada dasarnya mengembangkan usaha sebagai PKL dianggap mempunyai nilai strategis, sementara ketika mereka harus berhadapan dengan resiko usaha - seperti menghadapi operasi penertiban - akan dicari akan dicari sejumlah strategi oleh masing-masing pelaku tindakan sosial tersebut. Dari sejumlah wawancara dan observasi di lapangan misalnya, sejumlah informan menempati lokasi adalah pilihan yang mereka yakini mampu menghasilkan keuntungan bagi dunia usahanya. Di sisi lain mereka melakukan aktivitas kesehariannya pada dasarnya didukung oleh sejumlah strategi untuk tetap bertahan dalam bidang usahanya. Katakanlah, menyangkut pendapatan diperoleh, menurut mereka menganggap pendapatan mereka dari usaha menjadi PKL jauh lebih besar dibandingkan ketika mereka masih menekuni dunia pertanian. Maka, para petani yang kemudian meninggalkan dunia pertanian statis itu berusaha berkerja di kota dan menekuni sektor informal, sebenarnya merupakan pilihan yang paling rasional untuk mengatasi kemiskinan di pedesaan.

Apalagi - seperti juga yang telah diungkapkan pada bagian sebelumnya sektor informal lebih berciri padat karya, tidak menuntut jenjang pendidikan yang terlalu tinggi, lebih mudah untuk keluar masuk menekuni bidang usaha tertentu, serta dapat dilakukan dari ruang lingkup keluarga. Bahkan, Papanek (1975) mengungkapkan, betapa pun kecilnya pendapatan yang diperoleh dari sektor informal di perkotaan, kesempatan kerja di kota dianggap jauh lebih baik daripada lapisan berpendapatan rendah di pedesaan Jawa.

Sejalan dengan itu, informan yang menjadi subjek penelitian ini juga memberi alasan bahwa pilihannya berkerja sebagai PKL di Kota Semarang, disebabkan di desanya tidak ada lagi jenis pekerjaan yang harus dikembangkan. Meskipun di desanya dia bisa bekerja di bidang pertanian namun dia tidak tertarik, karena dianggapnya kurang memberi peluang untuk berkembang maju.

Melihat kenyataan tersebut, persyaratan menekuni sektor informal seolah-olah tidak seberat dibandingkan sektor formal, namun bukan berarti setiap orang yang menekuni sektor informal dengan mudah bisa berkembang dan memperoleh penghasilan yang memadai secara cepat. Dengan elastisitas yang terdapat pada sektor informal, kemudian lebih memberi ruang untuk keluar masuk menekuni bidang usaha tertentu, mengakibatkan sektor ini banyak menarik minat sejumlah orang.

Akan tetapi, berdasarkan hasil observasi dan wawancara dengan informan, proses keberhasilan menekuni sektor informal justru harus melalui berapa tahap. Seperti yang diungkapkan informan bahwa daya tarik untuk menekuni sektor informal, bertolak dari keberhasilan yang telah dirasakan figur dalam lingkungan keluarga sebelumnya. Disebutkan, keberhasilan anggota keluarga yang telah lebih dahulu menekuni sektor tersebut mendorongnya untuk mengikutinya, meskipun harus dimulai dengan menjadi pembantu (kenek) kakak-kakaknya. Dengan menjadi kenek, berarti merupakan proses belajar yang paling mudah dilakukan untuk mengembangkan usaha lebih lanjut, baik menyangkut pemilihan jenis usaha, modal yang dibelanjakan, segmen pasar yang akan dijadikan sasaran, maupun kadar resiko yang bakal dihadapi.

Harus diakui bahwa keberadaan PKL Kota Semarang telah diatur oleh Perda No. 11/ 200o. Akan tetapi, kalau diperhatikan secara seksama Perda ini sebenarnya tidak secara spesifik mengatur keberadaan pedagang kaki lima, karena dalam Perda tersebut secara umum lebih mengarah pada peraturan ketertiban umum. Akan tetapi, ketika persoalan ketertiban umum menyangkut sarana ruang publik yang biasanya dijadikan lokasi usaha PKL, maka secara tidak lang- 
sung keberadaan pedagang kaki lima juga terkait dengan Perda tersebut.

Bertolak dari Perda tersebutlah aparat Pemkot - terutama melalui petugas Satpol PP dengan mengatasnamakan ingin menciptakan ketertiban umum -- mempunyai otoritas kekuasaan untuk menentukan keberadaaan pedagang kaki lima. Dengan berpegang pada Perda itu pula petugas Sarpol PP - dengan mengatasnamakan penegakkan hukum dan aturan - mempunyai kewenangan untuk menertibkan, mengatur, dan melarang usaha pedagang kaki lima.

Dari sinilah terlihat bahwa persoalan kekuasaan memainkan peranan. Bagi petugas Satpol PP misalnya, mengekspresikan kekuasaannya dengan tindakan sosial seperti melakukan operasi penertiban. Operasi penertiban tersebut, di satu sisi merupakan implementasi dari penerapan Perda yang berlaku. Namun, di sisi lain, dengan operasi penertiban pula membawa implikasi pada sanksi hukum bagi para pedagang kaki lima. Sanksi hukum yang berlaku tidak semata-mata berupa tindakan menghentikan usaha pedagang kaki lima, tetapi sanksi tersebut pada dasarnya juga bisa dalam bentuk "negosiasi-negosiasi" yang kemudian berujung pada munculnya "uang tebusan" yang harus dikeluarkan oleh para pedagang kaki lima. Besaran uang tebusan juga akan tergantung dari keputusan aparat "penegak hukum" tersebut.

Sanksi hukum, uang tebusan, besaran uang tebusan, bahkan juga pertangungjawaban uang tebusan tersebut, ternyata berdasarkan hasil wawancara dan observasi di lapangan lebih menunjukkan gambaran yang buram. Adanya pembayaran uang kebersihan dan keamanan yang setiap minggu dan bulan harus dikeluarkan pedagang kaki lima kepada petugas Pemkot, ternyata tidak berdasarkan Perda yang pasti.

Atas dasar aliran keuangan yang tidak jelas itulah, maka aparat Pemkot mampu mempermainkan kekuasaannya yang tidak jelas pula batasannya. Apalagi, pada tingkat kecamatan juga memiliki kewenangan untuk melakukan penertiban dalam wilayah administrasi kecamatan. Demikian pula pada tingkat kelurahan, juga memiliki ke- wenangan untuk melakukan penertiban dalam lingkungan kerjanya dalam lingkup yang lebih kecil.

Jika demikian kenyataannya, maka aparat Pemkot dari tingkat kota hingga tingkat kelurahan mempunyai posisi yang cukup strategis dalam memainkan kekuasaan terhadap para PKL. Akan tetapi, berdasarkan wawancara dan observasi di lapangan ternyata membuktikan bahwa para PKL secara tidak sadar telah memerankan kekuasannya pula. Dengan mempertahankan lokasi usaha, mendasarkan dagangannya di sela-sela tempat pejalan kaki, serta membatasi kehadiran pedagang kaki lima yang lain, adalah bagian dari ekspresi kekuasaan yang sedang mereka mainkan. Kendati sejumlah orang justru merasa tertolong dengan kehadiran para PKL, namun, tak jarang sejumlah orang juga merasa terganggu lantaran ruang publik berupa jalan yang dilaluinya lebih banyak dipenuhi PKL. Dan, atas nama ruang publik pula, para pedagang kaki lima mengklaim mempunyai hak untuk menggunakan kekuasaannya berjualan di sana.

Melihat gambaran tersebut seolah mengingatkan kita tentang isu kekuasaan yang pernah diungkapkan Bourdieu (1977). Dalam konsepnya tentang peran agen dan struktur sosial, Bourdieu memandang bahwa pada pikiran manusia ada skema-sekma yang bekerja secara tersirat, memberikan gambaran tentang sesuatu yang dilihatnya, ketika dia ada dalam lingkungan tertentu, terjadi interpretasi tertentu. Skema interpretasi ini penting agar orang dapat menyesuaikan diri di lingkungan barunya dan eksis di situ. Skema-skema interpretif ini bekerja tanpa disadari, memberikan gambaran bagaimana dunia bekerja, bagaimana menanggapi dan menilai sesuatu di lingkungan dan mengarahkan tindakan. Di sinilah memprodukkan habitus, artinya habitus adalah produk kondisi-kondisi struktur dari individu dan sekaligus praktek-praktek sosialnya yang kemudian mereproduksikan kondisi-kondisi objektif eksitensi sosial dari agen. Jadi reproduksi sosial adalah proses, bukan mekanistis atau instrumen, arahnya pada habitus yang menjadi produk kondisi struktur dari individu. 
Bourdieu mengklarifikasi dikotomi, mikro yang bekerja pada tingkat individu atau antarpribadi dan makro sebagai produk dan produser struktur sosial, serta melihat habitus bekerja dalam kaitan dengan field dan capital (Bourdieu, 1977: 23-24). Dalam kehidupan sosial sehari-hari Bourdieu (1977: 51-54) justru memandang adanya kontestasi kekuasaan. Apalagi, menurutnya, kebudayaan sebagai simbol dan makna yang membentuk dominasi sosial yang nyata sehari-hari, di situlah tampak adanya kekerasaan simbolik. Kekerasan simbolik merupakan kekerasan yang dikenakan pada agen-agen sosial tanpa mengundang resistansi, sebaliknya malahan mengundang konformitas sebab sudah mendapat legitimasi sosial karena bentuknya yang sangat halus. Bahasa, makna dan sistem simbolik para pemiliki kekuasaan ditanamkan dalam benak individu-individu lewat suatu mekanisme yang tersembunyi dari kesadaran (Bourdieu, 1977: 51-52). Bila Marxis melihat fungsi politis sistem simbolik pada kepentingan kelas dominan dengan problem kesadaran palsu yang terdapat dalam kelaskelas yang terdominasi. Bourdieu mereduksikan relas-relasi kekuasaan menjadi relasirelasi komunikasi. Karena itu fungsi politik dari sistem simbolik merupakan upaya sistematik untuk melegitimasi dominasi dengan memaksakan defenisi dunia sosial yang benar dan legitimit. Bordieu melihat sebenaranya dalam kehidupan sehari-hari masyarakat ada saja konflik simbolik melalui penggunaan kepada kerasaan simbolik oleh yang dominan atas yang terdominasi.

Contoh pengalaman sejumlah informan dalam penelitian ini dapat dijadikan bukti kongkrit gambaran fenomena tersebut. Bahkan gambaran yang lebih nyata dapat diperhatikan dari siasat-siasat yang dimainkan sejumlah PKL. Dari sinilah terlihat bahwa kekuasaan terdistribusi di semua relasi sosial. Kekuasaan terjalin dalam jaringan seluruh tatanan sosial, karena itu kekuasaan lebih bersifat produktif, di mana kekuasaan menghadirkan subjek. Kekuasaan berimbas pada pembentukan kekuatan, menjadikan subjek tumbuh dan mencari dirinya, ketimbang menghalangi, membuat subjek menyerah atau menghancurkan. Kekuasan muncul karena adanya pengetahuan akan ruang yang digunakan. Bila Pemda memandang ruang publik harus dibungkus dengan aturan hukum, maka pengetahuan yang tertanam pada diri pedagang kaki lima ruang publik adalah lokasi yang berhak diakses olehnya untuk mengembangkan usahanya.

Sejalan dengan dengan pernyataan tersebut Foucault (1980:136) mengatakan, ada hubungan timbal balik yang saling mendukung antara pengetahuan dan kekuasaan. Pengetahuan tidak dapat dipisahkan dari rezim kekuasan. Pengetahuan terbangun dalam praktek kekuasaan dan ia membangun perkembangan, perbaikan dengan teknik baru kekuasaan, karena tidak ada sumber kekuasaan yang tunggal. Melainkan kekuasaan diyakini tersebar di mana-mana, dan konflik sebagai salah satu bentuk konsekuesinya. Dengan demikian kekuasaan bukan institusi bukan juga struktur, bukan pula kekuatan yang dimiliki, melainkan suatu istilah untuk menyebut suatu situasi strategis yang kompleks dalam suatu masyarakat. Oleh sebab itu, Foucault (1980) menawarkan sebuah model berpikir yang diatur secara dialektis melakukan strategi perlawanan. Bila perlawanan dilakukan dalam bentuk aksi lokal, yang radikal, maka perlawanan itu harus merusakan dan menghancurkan, merobohkan, struktur dan sistem yang ada, agar terjadi perubahan sesungguhnya. Bila perlawanan tidak radikal, seluruh struktur dan sistem tidak roboh, sehingga perlawanan di sini hanya membutuhkan pengorganisasikan kembali sektor-sektornya.

Dari hasil wawancara dengan sejumlah informan dan observasi di lapangan, memberi gambaran bahwa membuka usaha PKL pada dasarnya tidak aman dan rentan dengan sejumlah resiko. Akan tetapi, masing-masing pedagang kaki lima justru telah mempersiapkan sejumlah strategi untuk mengatasi resiko tersebut.

Katakanlah, ketika mereka harus menghadapi operasi penertiban sehingga kemudian mereka merelakan gerobag dan barang daganganya diangkut petugas penertiban, akan dilakukan siasat-siasat untuk mengatasinya. Misalnya, mereka harus 
menjalin kerja sama dengan oknum petugas kelurahan atau kecamatan tentang kapan pelaksanaan operasiakan dilakukan. Kalau saja sampai terjaring operasi pun mereka sudah siap menghadapinya. Bahkan, ketika harus digusur dari lokasi semula pun masing-masing pedagang kaki lima juga mempunyai kiat untuk mengatasinya.

Yang menarik dari gambaran tersebut adalah, ketika aparat Pemkot memperingatkan untuk tidak membuka usaha di ruang publik, ketika operasi penertiban, atau bahkan ketika eksekusi penggusuran dilakukan, tidak ditanggapi dengan perlawanan berupa ekspresi kekerasan. Mereka seolah patuh dan mengindahkan sejumlah "aturan main" tersebut. Akan tetapi, setelah peringatan, operasi penertiban, dan bahkan eksekusi penggusuran berlangsung, mereka kembali menerabas "aturan main" tersebut. Dari sinilah terlihat adanya bentuk perlawanan yang diekspresikan secara malu-malu.

Perlawanan tersebut malu-malu tersebut, yang secara konseptual terkait dengan pengertian resistansi berupa kiat-kiat atau cara-cara dominasi antara satu pihak kepada pihak yang lain. Sebaliknya pihak yang lain dengan taktiknya melawan pihak yang mendominasi. Atau juga pihak yang mendominasi dapat menggunakan starteginya untuk mempertahankan fungsinya. Resistensi tidak hanya ditemukan dalam hubungan -hubungan ekonomi (hubungan kerja), tetapi juga dalam hubungan-hubungan sosial lainnya, yang ditemukan dalam kehidupan sehari-hari. Dalam hal ini resistansi lebih ke arah interaksionis simbolik yang memusatkan perhatian pada makna dan simbol terhadap tindakan dan interaksi manusia. Atau dengan kata lain, resistansi muncul sebagai salah satu bentuk kekuatan yang mendorong kehidupan masyarakat menciptakan gerakan perubahan.

Jika mengacu pada pendapat Barker (2003: 358), maka dua kekuatan merongrong kehidupan masyarakat untuk berubah, yakni masalah ekonomi dan kekuasaan. Keduanya merupakan simbol kekuatan yang melahirkan perubahan dalam masyarakat. Apakah perubahan itu dinamik atau statis, tergantung kekuatan resistansi tersebut. Demikian juga pendapat Bennett (1982: 171) bahkan melihat perlawanan pada dasarnya adalah hubungan defensif, dengan kekuasaan budaya yang diadaptasi oleh kekuatan sosial subordinat dalam situasi di mana bentuk-bentuk kekuasaan budaya tersebut muncul dari suatu sumber yang jelas dialami sebagai sesuatu yang bersifat ekstranal. Perlawanan dalam hal ini berakar pada kondisi budaya kelas pekerja, yang berhadapan dengan budaya kelas berkuasa. Bentuk perlawanan menurut Bennett secara samar-samar sebagai respons atas kekuasaan.

Demikian juga pendapat de Certeau (1984) yang membedakan antara strategi kekuasaan dengan taktik perlawanan. Strategi adalah instrumen yang digunakan kekuasaan yang menciptakan suatu ruang bagi dirinya dan terpisah dari lingkungannya untuk mengoperasikan objek kehendaknya. Jadi kekuasan suatu perusahan ada pada ruang dan sarana bagi dirinya yang digunakan untuk bertindak secara terpisah dari pesaing, musuh, klien, dll. Sebaliknya taktik adalah permainan jebakan, tipu daya, pemalsuan kehidupan sehari-hari dengan menggunakan sumberdaya yang ada serta berusaha menciptakan ruang yang dapat ditinggalkan.

Untuk itulah, jika kita coba perhatikan sejumlah tindakan sosial yang dilakukan para PKL berupa ekspresi perlawanan malumalu ini kita golongkan dalam bentuk resistansi non-violent. Di satu sisi, mereka juga menyadari bahwa usaha yang dialakukan adalah bertentangan dengan aturan main yang ada. Akan tetapi, di sisi lain mereka harus mempertahankan ranah sosial melalui habitus-habitusnya, karena capital yang telah mereka miliki juga harus dipertahankan. PKL juga mengerti bahwa bahwa ruang publik, bahu jalan, halte bus adalah lokasi terlarang untuk membuka usaha. Mereka juga paham jika operasi penertiban akan selalu dilakukan serta reskio-resiko yang bakal menimpanya. Akan tetapi mereka juga mempunyai pengetahuan untuk menyiasati resiko-resiko tersebut, demi mempertahankan eksistensinya. Dari sinilah terlihat tentang sejumlah strategi yang dikembangkan 
para PKL - khususnya yang ada di Kota Semarang - yang secara tidak langsung juga merupakan bagian dari jaringan sosial yang mereka ciptakan selama ini.

\section{SIMPULAN}

Berdasarkan sejumlah uraian terdahulu dapat disimpulkan dalam penjelasan sebagai berikut:

Pertama, para petani yang kini cenderung meninggalkan dunia pertanian dan memasuki sektor informal di perkotaan lebih memilih jenis pekerjaan yang mereka kuasai sesuai dengan keahlian yang mereka miliki dari desa. Jika mereka memilih jenis pekerjaan yang sesuai dengan keahlian yang dimiliki dari desa, maka mereka akan cenderung memilih sejumlah jenis pekerjaan yang ada kaitannya dengan dunia pertanian.

Kedua, jika memilih pekerjaan yang ada kaitannya dengan dunia pertanian, maka di kota dibutuhkan lahan pertanian yang memadai untuk menampung pekerjaan mereka. Akan tetapi, jika ternyata lahan tersedia di perkotaan lebih cenderung mengakomodasi sektor industri dan jasa, maka yang harus dilakukan para petani tersebut untuk beralih ke sektor lain yang bisa jadi tidak berkaitan dengan dunia pertanian, yang lazim disebut sektor informal.

Ketiga, kendati mereka memilih pekerjaan sektor informal, namun sejumlah keahlian yang didapat dari desa di luar sektor pertanianlah masih dicoba untuk dikembangkan ke kota. Akan tetapi, jika kemudian mereka berusaha mengembangkan keahlian di luar sektor pertanian, maka sejumlah ketrampilan yang didapatkan dari lingkungan keluargalah yang dijadikan sarana untuk menguasai jenis pekerjaan di perkotaan.

Keempat, tindakan sosial manusia menekuni bidang usaha PKL pada dasarnya bertolak dari pertimbangan rasional. Latar belakang dunia pertanian para PKL mendorong mereka mengembangkan jaringan sosial dan strategi menekuni sektor informal di perkotaan (Kota Semarang), apalagi lebih ditandai oleh peran dan fungsi keluarga dalam mendukung strategi tersebut.

Kelima, keberadaan PKL di perkotaan sangat menandai dinamika dan mobilitas di perkotaan. Bahkan, keberadaan pedagang kaki lima merupakan salah satu pekerjaan yang penting dan nyata di sejumlah negara berkembang, terutama berkaitan dengan proses urbanisasi dari desa ke kota dan pertumbuhan kesempatan kerja yang lambat dalam sektor industri.

Keenam, kebijakan pemerintah yang tertuang dalam Perda justru tidak efektif mengatur keberadaan PKL. Bahkan dapat dikatakan bahwa aturan-aturan dan normanorma itu justru seringkali "dilawan" oleh subjek pelaku secara aktif, kreatif, bahkan manipulatif dalam menghadapi lingkungannya yang terekspresi dalam tindakan sosialnya. Hal itu terjadi, karena sebagai subjek pelaku (manusia) senantiasa berusaha untuk memanipulasi keteraturan normatif. Dari sinilah sejumlah strategi yang dikembangkan para PKL yang secara tidak langsung juga merupakan bagian dari jaringan sosial yang mereka ciptakan selama ini.

Ketujuh, PKL bukanlah semata-mata beban atau gangguan bagi keindahan dan ketertiban kota. PKL juga punya hak hidup dan mendapatkan penghasilan secara layak, akan tetapi alasan seperti ini jangan sampai digunakan para PKL untuk berusaha tanpa mematuhi aturan karena tidak semua lokasi bisa dipakai sebagai tempat usaha. PKL sesungguhnya juga merupakan aset dan potensi ekonomi jika benar-benar bisa dikelola dengan baik. Masalah yang muncul berkenaan dengan PKL ini adalah banyak disebabkan oleh kurangnya ruang untuk mewadahi kegiatan PKL di perkotaan.

\section{DAFTAR PUSTAKA}

Ali, M. 1989. "Keberadaan Pedagang Kaki Lima di Kotamadya Surabaya Dalam Konteks Pembinaan Ketaatan Hukum". (Hasil penelitianSurabaya).

Astono, M.A.D. dan I.A. Soembogo. 2005."Kebudayaan sebagai Perilaku” dalam Teori-Teori Kebudayaan (ed. Mudji Sutrisno \& Hendar Putranto). Yogyakarta: Penerbit Kanisius.

Barker, C. 2003.Cultural Studies: Theory and Practice (2nd edition). London: SAGE Publishers.

Bennet, T. 1982."Media, Reality Signification” dalam Michel Gurevitch (ed), Culture, Society and the Media. Metheun 
Blumer, H. 1969. Symbolic Interaction. New York: Prentice Hall.

Bogdan, R dan Steven J. Taylor. 1993. Kualitatif Dasardasar Penelitian (terjemahan). Surabaya: Usaha Nasional.

Boiroh, P, 1973. Urban Unemployment in Developing Countries. Geneva: International Labor Office. 477-492

Bourdieu, P. 1977. Outline of a Theory of Practice. Cambridge: Cambridge University Press.

Breman, J.C. 1980. The Informal Sector in Research, Theory and Practice. Roterdam: Eramus University

Bromley, R. 1978. "Organitation, Regulation, and Eploitation in the socalled "Urban Informal Sector: The Street Traders of Cali, Colombia" dalam World Development. Great Britain: Pergamon Press. 6(9/10):1161-1711

Creswell, J W. 1994. Reseach Design. Qualitative $\mathcal{E}$ Quantitative Approache. USA: SAGE Publication.

de Certeau, M. 1984. The Practice of Everday Life. Berkeley: University of California Press

Ernawati, dan Jenny Suharso, Tunjung W.Subekti, Harini. 1995 "Preferensi Pedagang Kaki Lima Terhadap Faktor-faktor Lokasi Tempat Mangkal Dalam Melakukan Aktivitas Perdagangan di Kotamadya Malang".(Hasil penelitianMalang).

Foucault, M. 1980.Power/ Knowledge: Selected Interview $\mathcal{E}$ Other Writing. New York: Pantheon.

Geertz, H. 1985. Keluarga Jawa (terjemahan). Jakarta: Grafiti Pers (cetakan III)

Goffman, E. 1974 Frame Analysis. An Essay on the Organization og Experience London: Harper \& Row Publishers

Hatta, Moch. 1992. "Sosok Kehidupan Sosial Ekonomi Pedagang Keliling Sayuran di Kompleks Perum Riung Bandung,, (Hasil penelitianBandung)

Jamuin, M. 200o. "Perilaku Ekonomi Pedagang Warung Tenda Dalam Krisis Moneter", (Hasil penelitian- Surakarta).

Koentjaraningrat. 1993. Metode-Metode Penelitian Masyarakat (Edisi Ketiga).Jakarta: Gramedia Pusataka Utama.

Latief, M A. 1997. "Pola Berdagang di Kalangan Pedagang Informal diKotamadya Banda Aceh", ( Hasil penelitian- Darussalam).

Lubis, P.W. dan Rohman. 1998. "Peranan Pedagang Kaki Lima Dalam Meningkatkan Pendapatan Keluarga di Kotamadya Jambi”, (Hasil penelitian- Jambi)

Lukman .1995. "Pembinaan Pedagang Kaki Lima: Evaluasi Proyek Citra Niaga di Kotamadya Samarinda” (Hasil Penelitian-Yogyakarta).

McGee, 1976. "Hawkers and Hookers: Making out in Third Word City: Some Southeast Asian Examples" dalam Manpower and Unemployment Research. 9(1):3-22.

Mead, G.H. 1934. Mind, Self and Society (ed. Charles W. Morris). Chicago: University of Chicago
Press

Munir, H.M. Salim. 1993. "Hubungan Patron Klien Pedagang Daging Sapi dan Tingkat Kesejahteraan Pengecer di Pasar Krian, Kecamatan Krian, Kabupaten Sidoarjo" (Hasil penelitianYogyakarta)

Muthmainah. 1993. "Faktor-faktor yang Mempengaruhi Keberhasilan Pedagang Informal Serta Peranannya Dalam Kesempatan Kerja dan Penghasilan Keluarga di Kotamadya Surakarta”, (Hasil penelitian-Surakarta).

Ngatno. 1996. "Analisis Pemanfaatan Kredit Bagi Pedagang Kaki Lima di Kotamadya Semarang", (Hasil penelitian- Semarang).

Papanek, G.F. 1975. "The Poor of Jakarta" dalam Economic Development and Cultural Change. 26: 1-27

Pelto, P.J., dan Gretel H.Pelto. 1978. Anthropological Research. Cambridge: Cambridge University Press.

Rayeuk, Abdullah. 1993. Laporan penelitian dengan judul: "Tingkat Fertilitas Penduduk yang Bekerja Pada Sektor Non-formal: Studi Kasus Pedagang Kaki Lima Kodya Banda Aceh", (Hasil penelitian- Banda Aceh).

Rini, H.S. 2012. "Dilema Keberadaan Sektor Informal" dalam Jurnal Komunitas, Research and Learning in Sociology and Anthrophology, 4(2)

Saifuddin, A.F. 2005. Antropologi Kontemporer: Suatu Pengantar Kritis Mengenai Paradigma. Jakarta: Kencana Prenada Media

Saleh, C. 1995. "Relokasi dan Perilaku Ekonomi Pedagang Besi Tua: Penelitian di Daerah Tingkat II Kodya Surabaya”, (Hasil penelitian-Yogyakarta).

Surya, O.L. dan Retno Widjajanti. 2007. Jurnal Tata Loka. 9(3)

Sanchez, C.E., Horacio Palmeiro, dan Fernando Ferrero. 1981. "The Informal and Quasi Informal Sector" dalam The Informal Sector in Developing Countries (S.V. Sethuraman. Ed). Geneva: ILO

Sayogo. 2002. "Pertanian dan Kemiskinan”. Makalah disampaikan pada Pertemuan II Seminar Pendalaman Ekonomi Rakyat, YAE-Bina Swadaya, Finacial Club Jakarta, 5 Februari 2002.

Spradley, J.P. 1980. Participant Obeservation. New York: Holt, Rinehart, and Winston.

Suhariyanti, Sulistyo, Tina A.N, dan Nila Firdausi. 1995. "Jaringan Sosial Pedagang Kaki Lima di Perkotaan: Suatu Studi Pada Pedagang Kaki Lima di Perkotaan Kotamadya Malang”, (Hasil penelitian- Malang).

Susilowati, D. 1997. "Associations Between Anthropometric Measurement and Socioeconomic Situation in East Jakarta Households: Explanations of Over and Underweight Distributions Among Household Members" (Hasil penelitian-Jakarta).

Sutrisno, M. 2003. Diktat Filsafat Kebudayaan. Jakarta: STF Driyarkara

Tantu, H. 1992."Kehidupan Pedagang Kaki Lima Asal 
Jawa, Bali dan Madura di Sulawesi Selatan : Suatu Analisa Peran Sektor Informal Sebagai Pendorong Transmigrasi Spontan di Indonesia”, (Hasil penelitian- Ujung Pandang).

Vayda, A.P. 1983 ."Progresive Contextualization: Methods for Research in Human Ecology", Human Ecology. 11: 265-281.

Sumber Internet:

http://www.vhrmedia.com/PKL-Semarang-TolakPenggusuran-berita2493.html) 23/7/2010 http://hetifah.com/artikel/penyebab-gagalnyapengelolaan-pkl-di-perkotaan.html diunduh 23/6/2010

http://www.scribd.com/doc/3499983/Formulasi-Kebijakan-Publik diunduh 23/6/20

http://ratnadwipa.blogspot.com/20o8/12/agendasetting-dan-perumusan-masalah.html diunduh 10/7/2010

http://widytaurus.wordpress.com/2008/02/15/penggusuran-pkl-salah-siapa/ diunduh 6/7/2010

http://www.scribd.com/doc/23887284/Policy-PaperSanitasi-Lingkungan diunduh 6/7/2010 